\title{
Ireland's EEC Enlargement Negotiations and the Common Fisheries Policy, 1970-1972: Challenging the Acquis
}

\author{
Michael J. GEARY
}

Charles de Gaulle's unexpected departure as President of France in April 1969 ultimately paved the way for the European Economic Community (EEC) to begin its historic first round of enlargement negotiations. Britain, Denmark, Ireland, and Norway had queued for membership since the early 1960s, and that goal was now within reach. The last hurdle was the accession talks. Although the volume of scholarly literature on the first enlargement has grown in the last number of years, many aspects to that round, especially those linked to the three less important applicants, remain unexamined. This article analyses the most important issue that dominated the negotiations between Dublin and Brussels during the eighteen months of enlargement talks between mid-1970 and early 1972, namely the Common Fisheries Policy (CFP). ${ }^{1}$ It offers a fresh perspective on those talks by exploiting Irish and Community archival material. It traces the origins and development of the CFP, the unscrupulous attempts by the Community to integrate the policy into the acquis communautaire during the negotiations and Dublin's efforts to have the policy shelved until after the Community enlarged. Central to the article is an exploration of the way Dublin and Brussels tried to outmanoeuvre each other on the CFP issue while at the same time ensuring that the negotiations would succeed.

Due to Ireland's relative size, and pro-EEC outlook, negotiating membership should have been a straightforward affair. Ireland was not a member of the Commonwealth or the European Free Trade Association (EFTA), although it had a close economic relationship with Britain that needed attention. Domestically, there was no serious political opposition to membership. Fianna Fáil, the governing party, had originally applied for membership in 1961 and the party had remained in power since then, continually advocating for accession. Indeed, of the four applicants, Ireland was perhaps the staunchest advocate for membership, a policy position largely driven by a desire to gain access to the Common Market and to the Community's generous Common Agriculture Policy (CAP). Patrick Hillery, Ireland's Minister for Foreign Affairs, was appointed to lead the Irish delegation in Brussels, and was assisted by many of those who had worked on Dublin's first application for membership a decade earlier. ${ }^{2}$ Between The Hague Summit of December 1969 and the opening of negotiations seven months later, the government sought to convey the message that Ireland was willing to accept the acquis as well as the political implications vaguely associated with membership.

1. I would like to thank the Institute for European Global Studies, University of Basel, for providing financial support to complete this article as well as an anonymous referee for valuable suggestions.

2. For more on the first Irish application for EEC membership, see M.J. GEARY, An Inconvenient Wait: Ireland's Quest for Membership of the EEC, 1957-73, Institute of Public Administration, Dublin, 2009, pp.9-52. 
In meetings with the EEC six and the Commission, Hillery highlighted the need for the simultaneous opening and closing of negotiations and accession for Ireland and Britain; Denmark had been pushing for something similar. ${ }^{3} \mathrm{He}$ also stressed the importance of consultations on matters of common interest to all the applicants as they arose during the negotiations. ${ }^{4}$ Between January and June 1970, not only did Irish government Ministers visit the capitals of the six, the Commission, and the applicant counties, the government also published a White Paper on membership that was generally well received in the Community, and completed its negotiating positions on a wide range of issues. Irish diplomats in Brussels played a key role in this process with clear direction from Hillery. In the aftermath of The Hague Summit, Seán Kennan, Ireland's ambassador to the EEC, offered Dublin the following advice on how to proceed with a renewed application:

"(i) Avoiding disclosure of information which would prejudice our negotiation position (ii) avoiding disclosure of confidential information, such as conversations with Commissioners (iii) avoiding publication of evaluations or judgements of a sensitive nature, 'our attitude as regards New Zealand butter and lamb' (iv) bearing in mind that whatever was published would in all probability be studied in Brussels, projecting the image of a country ready and able to accept all the obligations (political as well as economic) of full membership, to play a constructive part in the further development of the Communities and not 'concerned exclusively or mainly with the economic payoff particularly in agriculture', and (v) to a very limited extent "factual accuracy".

Kennan stressed: "We also have to bear in mind the sensitive issue of agricultural surpluses within the EEC". 5 The Irish government did not want to attract too much unwelcome attention towards its principal exports, such as butter. After all, by the end of the 1960s, the Community had surpluses in many of the dairy commodities that Dublin wished to export. Ireland's membership would only add to the Community's butter mountain and by extension, additional costs to the CAP. While the economic benefits were the principal motivation behind the Irish application, it was important to show Brussels that Ireland was also interested in other, more political aspects of the integration process. At a meeting with Irish ambassadors to the capitals of the EEC six, Hillery stressed that his government had indicated publicly that it was prepared to participate in a European defence community and warned his diplomats to discourage any comparisons between Ireland's version of neutrality and that of the established neutrals, Austria, Sweden, and Switzerland. The evidence suggests that the pre-Second World War policy was not set in stone and if it became an obstacle to accession, Dublin seemed ready to abandon it.

3. M. RASMUSSEN, Joining the European Communities: Denmark's Road to EC-Membership, 1961-1973, Ph.D. Thesis, European University Institute [Florence], 2004, p.179.

4. NAI [National Archives of Ireland], Department of Foreign Affairs (hereafter: D/FA) 2003/1/183, note of meeting between Irish officials in Brussels, and Dirk Spierenburg, Dutch permanent representative to the EEC, 14.05.1970.

5. NAI, D/FA 2003/1/248, Observations from Kennan in document entitled 'Membership of the European Communities', 10.12.1969. 
Apart from these policy considerations, Dublin had a significant interest in Britain's negotiations with the EEC. After all, the Danish and Irish applications were largely tied to the apron strings of the British application. Keeping an eye on London was a prime concern for both Dublin and Copenhagen and there is sufficient evidence to suggest that the latter never fully trusted London to keep them informed on matters of mutual interest. George Thomson, a British Foreign Office Minister before the talks opened, appeared willing to keep the channels of communication open during the accession discussions but Dublin remained suspicious. Hillery urged his diplomats to be "very much on the alert for possible moves by the British to seek accommodations with individual EEC governments" - this was in response to early indications that some attempt at a Franco-British dialogue was likely. ${ }^{6}$ Throughout the spring and summer of 1970, Irish and Danish officials complained privately that London might not be a helpful negotiating partner. Erling Kristiansen, Denmark's ambassador to London told Donal O'Sullivan, his Irish counterpart, that his government had learned lessons from the 1961-1963 negotiations. Denmark had, he said, "first hand experience of how loosely the British can interpret an undertaking" to brief their partners in the EFTA. ${ }^{7}$ Kevin Rush, chargé d'affaires at the Irish embassy in London, wrote a highly negative report based on a meeting he had with Geoffrey Rippon, head of the British negotiating team in Edward Heath's Conservative government. He concluded that Rippon was

"a small town politician trying too hard to say the right thing with transparent insincerity ... genial, hearty, typically British and obviously quite insincere". ${ }^{8}$

Managing relations with the other applicants would prove an important but challenging process once the talks commenced in the autumn of 1970.

Having accepted the acquis at the opening meeting between the Community and the four applicants on 30 June 1970, the real negotiations for Ireland began the following September. Prior to the first ministerial meeting with Dublin, there was very little discussion within the Community about the Irish application. It was clear to Brussels that Ireland's candidacy posed none of the more challenging problems associated with Britain's accession. At first glance, most, if not all, the problems, related to finding technical solutions. At the first ministerial session between the Community and Ireland on 21 September 1970 under the chairmanship of Walter Scheel, West German Foreign Minister, Hillery outlined eight key areas that Dublin prioritised for discussion including the transition period, customs union, CAP, fisheries, trade relations with Britain, Ireland's contribution to the EEC's budget, economic and monetary union, and a number of relatively minor issues. Hillery supported the Commission's position on the transition period, especially the parallelism between the achievement of the free movement of industrial goods, and the common market for agricultural products. He also supported the Commission's view that the transition

6. NAI, D/FA 2003/1/434, Meeting of the ambassadors of the six and applicants at the embassy in Paris on 14 December $1969,17.12 .1969$.

7. NAI, D/FA 2003/1/407, Donal O'Sullivan, Irish ambassador, to Secretary D/FA, 01.06.1970.

8. NAI, D/FA 2003/1/407, Rush to Secretary D/FA, 13.08.1970. 
period would be the same for the four applicants. ${ }^{9}$ While Dublin had been a supporter of the CAP since the policy was first developed in the late 1950s, it paid special attention to the British negotiations on this issue for fear that London would negotiate special arrangements for third countries, such as New Zealand, that could affect Ireland's export trade to its nearest neighbour. Unlike Britain, Ireland had accepted the Community's finance system from the outset. This was a minor issue since Ireland's contribution to the Community's budget would be small in comparison to the gains it was likely to make from the CAP and other funds. Yet, it was the introduction of the EEC's new Common Fisheries Policy in June 1970 that caused the greatest strain in relations between Dublin and Brussels during the course of the negotiations. The origins of the policy and its impact on the accession talks are examined in the remainder of the article.

\section{The Fisheries Policy}

Most of the main agricultural products in the Community were subject to a common policy by mid-1968 under the CAP. Fish and fish products had not been included despite coming within the Treaty of Rome definition of agricultural products. The Treaty was silent on the type of policy that should regulate the Community's fishing industry; there was large scope for interpretation. In many ways, the origins of the CFP could be linked to the problems that had confronted the French fishing industry during the early part of the 1960s. By 1962, that industry found itself increasingly threatened by competition from cheaper foreign fish imports from member and nonmember states. Fish trade was also being liberalised within the framework of the GATT. As a result, imports into France rose significantly, from 95,000 tons in 1957 to 242,000 tons in $1962 .{ }^{10}$ It was at this point that the French government lobbied the Community for a common fisheries policy to help its fishing industry cope with the extra competition.

The Hallstein Commission proved rather receptive to the French position despite lukewarm responses from France's EEC partners who were worried about the costs associated with another new policy. It was perhaps no surprise that the Commission became a supporter of a common policy covering the fishing industry. As the CAP had shown, common policies had the effect of bringing the six closer together but, crucially for the Commission, common policies deepened the integration process, and gave the Commission a greater role in influencing the policy-making process. With a green light from Paris, the Commission set about drawing up a common policy to regulate Community fishing. By 1968, the Commission had sent a package of

9. D. MAHER, The Tortuous Path: The Course of Ireland's Entry into the EEC, 1948-1973, Institute of Public Administration, Dublin, 1986, pp.274-275.

10. M. WISE, The Common Fisheries Policy of the European Community, Methuen, London, 1984, p. 87. 
proposals to the Council of Ministers. The 1968 fisheries proposals covered three main areas: (i) the common organisation of the fishery market; (ii) a common structural policy that included using EEC funds, and establishing common rules governing the granting of state aids; and (iii) equal conditions of access to fishing grounds. It was the third aspect of the Commission's proposals that caused the greatest problem at the enlargement negotiations. The Community's fishermen, the Commission argued, had to have

"equal access to and use of fishing grounds in maritime waters coming under the sovereignty or within the jurisdiction of member states". ${ }^{11}$

These access proposals were an integral part of the Commission's structural policy designed to eliminate national discriminations, and equalise conditions of competition. Moreover, the blueprint for a fisheries policy also showed how conscious the Commission was of the various national interests of the member states. The Germans and the Dutch, for example, insisted on the equal access provision, while France wanted the policy to include provisions where its fishermen could use Community funds to upgrade fishing fleets. Though the Commission's proposals made reference to overfishing and conservation, a serious concern for, or analysis of, conserving fishing stocks did not feature prominently.

Between 1968 and June 1970, agreement on the CFP was difficult to achieve in the Council because of the divergent interests of the six and is touched upon elsewhere. ${ }^{12}$ However, the Commission had made a number of compromises in order to bridge the divide, especially between France, Germany and the Netherlands over the issue of using Community funds to pay for the new policy. On 30 June 1970, the EEC had reached a less than perfect agreement on the fisheries policy. A deal was only possible after Sicco Mansholt, Agriculture Commissioner, had presented the six with a new set of proposals aimed solely at bringing closure to the CFP before the enlargement negotiations started that same day. By linking the issue of equal access to fishing waters, and the CFP structural fund, the Commission was at once able to reconcile French and German objections to the original Commission plan for the fishing industry. ${ }^{13}$ It was also decided that the CFP's final market, trade, and structural regulations would be formally adopted by the Council before 1 November $1970 .{ }^{14}$ Added to this, the Commission and the French insisted that the CFP be implemented in time to become part of the acquis which had to be accepted by the four aspiring members as a condition of membership.

While some officials might have seen the introduction of the CFP immediately prior to the opening of the enlargement talks as a "manifest error" on the part of the Commission, it was clear that the policy had broad backing from Commissioners and

11. Ibid., p.90.

12. See J. FARNELL, J. ELLES, In Search of a Common Fisheries Policy, Gower, London, 1984, chapter 1.

13. Agence Europe, 01.07.1970.

14. See M. WISE, op.cit., p.102. 
the political support of the six. ${ }^{15}$ Perhaps not without coincidence, the fisheries negotiations with the four applicants were not scheduled to start until early 1971 . The Council meeting at the end of October 1970 put the final CFP agreement together. The policy would enter into force on 1 February 1971, and become part of the acquis. In addition, the Council decided that any future revisions of the policy could only be made by the Foreign Ministers of the six who were also responsible for the enlargement negotiations, and not by the Community's Agriculture Ministers. This was another example of how the Community attempted to link the CFP to the acquis before the applicants had an opportunity to object to the policy while it was in the process of development and therefore more easily modified. Moreover, it showed how important politically the CFP was to the member states. Wresting control of the policy from the Community's Agriculture Ministers revealed how vital it was that the main provisions of the CFP remained in place. Arguably, the Foreign Ministers of the Community did not trust either Mansholt or the EEC Agriculture Ministers who might be more prone to compromise and negotiate away hard won ground by default. Indeed, it is also questionable whether this struggle was part of a general attempt by the Foreign Ministers to reign in specialist Councils in the later 1960s to prevent them from gaining too much decision-making power.

\section{Defending the acquis}

Prior to the first ministerial meeting in Brussels, Dublin had concluded that if the six adopted the CFP proposals before Ireland became a member or if the issue was raised during the negotiations "we should endeavour to maintain our existing exclusive fishery rights". ${ }^{16}$ Central to Irish concerns was the policy's equal access provision as well as fears of over-fishing. At the first ministerial meeting in September 1970, Hillery made clear that the equal access provision was a major issue because the Irish fishing industry was based on inshore fishing; Ireland had no deep-sea fishing fleet unlike the other applicants and some of the six. Dublin feared that better equipped fishing vessels would deplete Ireland's rich fishing stocks. The Community adopted a legalistic position to Ireland's concerns. The Council made clear that:

"it assumes, as a general principle, that the Applicant States accept the Treaties and all decisions of every kind taken from the entry into force of the Treaties until the end of the negotiations, and that the rule which must govern the negotiations is that the solution of

15. See J. VAN DER HARST, Enlargement: the Commission seeks a role for itself, in: M. DUMOULIN (dir.), The European Commission, 1958-72: History and Memories, OPOCE, Luxembourg, 2007, p.550; Historical Archives of the European Union, Voices on Europe Collection: R.P. Dingemans, J. Schram, Interview with Edmund Wellenstein, 10.07.1998.

16. NAI, D/FA 2003/1/230, Briefing notes for ministerial meeting with European Communities on 21 September 1970 - EEC Fisheries Policy. Ireland's exclusive fishery limits extended twelve miles seaward of the baseline of its territorial waters. This was in accordance with the Fisheries Convention signed in London on 9 March 1964. 
any problems of adjustment which may arise must be sought in the establishment of transitional measures and not by amendments of the existing rules". ${ }^{17}$

Furthermore, Dublin was reminded that CFP would be implemented before 1 November 1970; thereafter, any difficulties faced by the applicants could only be solved with transitional measures. Given the difficulty surrounding the adoption of the policy within the Council, it was logical that the Community wanted to protect the existing provisions of the hard fought policy. While there would be advantages for Ireland in the measures proposed by the Commission for market organisation, and in the provisions for Community financial aid for improving fishing fleets and facilities for research, common access to fishing waters would create "grave difficulties for Irish fishermen". ${ }^{18}$ For Ireland, the fisheries question was about competition, over-fishing and the potential death of an economically (and politically) important industry. Domestic calculations concluded that over 5,000 Irish jobs were endangered as a result of the Commission's policy. In stark contrast, Denmark accepted the CFP from the outset; its middle and distant fishing industry would benefit most of the policy's main provisions. ${ }^{19}$ Even though Ireland had opened an embassy in Copenhagen before the negotiations opened, in an effort to strengthen relations during the accession talks, it was clear that Dublin could not rely on Denmark for support against the policy.

While the Council had made clear its position on the CFP, which was in line with the Commission's internal thinking on the policy, the latter adopted a more defensive attitude in response to statements by the applicants and articles that appeared in the newspapers. One of the roles of the Commission was, after all, to defend the acquis. Speaking in Dublin in October 1970, Mansholt denied that the policy was as inflexible as suggested by its critics and believed that the likely outcome to the negotiations on fisheries would be a five-year transitional period during which access to waters within the three-mile limit would be restored to local populations depending essentially on coastal fishing, and one or more of the member states of the enlarged Community could propose an extension of this period. ${ }^{20} \mathrm{He}$ dismissed outright fears that the policy would lead to over-fishing and argued that small industries had nothing to fear from competition. The onus was on the applicants to modify their policy positions in order to meet the necessary requirements for membership. In Ireland's case, as Mansholt pointed out, its fishing industry had to adapt to survive, and while the Commission would help in this adaptation process, the CFP would not be changed.

17. HAEC [Historical Archives of the European Commission, Brussels], BAC 134/1987, no.98/3, European Community, Summary of conclusions from first ministerial meeting between Ireland and the Community, 21.09.1970.

18. NAI, D/FA 2003/1/441, D/FA memorandum, Negotiations with the European Communities - The Common Fisheries Policy, c. May 1971. Another significant development from the September meetings with the applicants was the Community's decision to grant 'special status' to the Norwegian fishing industry.

19. NAI, D/FA 2003/1/230, Irish Department of Agriculture and Fisheries memorandum in advance of first ministerial meeting with European Communities on 21 September 1970 regarding the CFP, c. September 1970.See also M. RASMUSSEN, op.cit., p.256.

20. NAI, D/FA 2003/1/550, Notes of comments made by Mansholt at Irish Council of the European Movement seminar, 29.10.1970. 
A prominent feature of the preliminary CFP discussions between Dublin and Brussels during the first six months of the negotiations was the continuity in the Community's position; the Irish delegation met with stiff opposition from the Commission and the Council. At the deputies' meetings on 20 October and 27 November, and at the ministerial meeting on 15 December 1970, Dublin continued its protests. In an attempt to placate the Irish negotiating team, the Council suggested in November that the Commission could liaise with Dublin to "obtain all the clarifications" regarding the scope and content of the fishing regulations. ${ }^{21}$ The Community clearly believed that contacts with the Commission would be enough to "allay Irish concern". If, however, talks with the Commission failed to adequately address Irish concerns, the Community stated:

"the latter [Ireland] could inform the Community delegation about them as soon as the common fisheries policy entered into force, whereupon the Community delegation would be willing to discuss them". ${ }^{22}$

The Community delegation attempted to play a rather clever game. The Council had instructed the Commission to talk with the Irish side but not to entertain Ireland's problems. Arguably, these technical talks were merely delaying tactics in order to keep the real negotiations away from the enlargement negotiations until the CFP became part of the acquis. The fact that the Community mentioned the possibility that talks with the Commission would not suffice was evidence that the EEC fully understood the level of potential difficulties ahead for the policy. Ireland was conscious of the need to act before the February deadline. However, the Community refused to entertain any calls from Dublin for the renegotiation of the CFP. From the September 1970 ministerial meeting until the end of the year, the Community delegation repeated the same line, namely, that the applicant countries

“acceptent les Traités et les dispositions de toute nature intervenues depuis l'entrée en vigueur des Traités jusqu'à la fin des négociations." 23

Any change to a particular aspect of the acquis would have had wider implications not just for the applicants negotiating membership but also for the six. Any modification in the policy would have to be agreed by the six and given the Community's history of disagreement, especially over the common policies, it was unlikely that the Commission would entertain making Ireland a special case even though special status had been conceded to Norway in its enlargement negotiations. The Commission's public silence on the CFP, with the exception of Mansholt's comments, was not wholly surprising because at the ministerial meetings it did not have the right to speak.

21. NAI, D/FA 2003/1/497, Comments on second deputies meeting, 27.11.1970 in 'Second Ministerial meeting - summary of conclusions', 15.12.1970. The summaries of the enlargement negotiation meetings used in this paper are the original copies distributed to the applicants after each meeting by the Community secretariat, and produced after ministerial and deputies meetings during the enlargement conference.

22. Ibid.

23. HAEC, BAC 134/1987, no.47, Minutes of Council of Ministers' meeting, Négociations avec l'Irlande, $2^{\mathrm{e}}$ session ministérielle, 15.12.1970. 
However, there was little need for the Commission to get directly involved in the enlargement discussions of the CFP at such an early stage of the talks. The Community, under the German presidency for the second half of 1970, had done an adequate job of defending the CFP. Moreover, the German government was a supporter of the very provision that Ireland had objected to, namely, equal access to the fishing waters of member states.

\section{Challenging the acquis}

At a number of informal meetings between the Commission and Dublin throughout early 1971, Brussels continued to adopt a defensive position towards the CFP. While accepting that Ireland would have initial problems with adapting to the policy, JeanFrançois Deniau, the French Commissioner and key Community negotiator, stressed that it could be possible to grant a concession covering the whole of Ireland or more probably covering certain areas. ${ }^{24}$ However, he cautioned that such concessions, even if they could be granted, were limited to a period of five years, and to fishing areas within a three-mile limit from the coastline. Given French scepticism towards the equal access provision, this was a good example of a Commissioner not acting as a proxy for national interests. Hillery pointed out the awkward reality that the four applicant countries would account for 60 per cent of the fisheries in the area that would constitute the enlarged Community. This created a new situation, one that the Commission must have been conscious of when drafting the policy, but Deniau was adamant that the principle of non-discrimination applied in relation to common access, a typical response from the Community. A far greater concern for Brussels was protecting the acquis, rather than bending the rules to accommodate the multitude of national interests of the four candidate countries and these interests were growing. Despite Denmark's broad support for the policy, it wanted special treatment for its two overseas territories, Greenland and the Faroe Islands. ${ }^{25}$

The CFP made a formal appearance at the negotiations during the third ministerial meeting with Ireland on 3 March 1971. Accepting that most aspects of the policy were fully acceptable to Dublin, Hillery stressed that the equal access provision was still a major issue; no amount of discussion would alter this fact. He reiterated with added force that Ireland could not accept the Community's CFP proposals as they stood. Even the Community's derogation mechanism built into the policy was

"limited both in scope and in duration, and recourse to it alone would not meet the special problems of the Irish fishing industry". ${ }^{26}$

24. NAI, D/FA 2002/19/304, Notes of meeting between Deniau and Hillery, 05.03.1971.

25. M. RASMUSSEN, op.cit., p.257.

26. NAI, D/FA 2003/1/474, Third Ministerial meeting - summary of conclusion, Statement by the Irish delegation on Common Fisheries Policy (Annex 1), 02.03.1971. 
Dublin adopted a new tactic a month later designed to put further pressure on the Community. At a meeting with the Commission, Dublin asked: If Norway received special treatment from the Community would Ireland get the same? Policy-makers in Dublin had known since the previous September that Norway was seeking special status for its fishing industry, something akin to a complete opt-out from the policy. A demand by Ireland for similar treatment was in many ways a questionable negotiating ploy that quickly became part of its formal negotiating strategy in Brussels and added further pressure on the Community to find a solution. Norway, of course, had much more to lose and, unlike the other applicants, it was unlikely to gain significantly from the CFP.

Ireland's position had evolved from concerns over the equal access provision to include the question of equal treatment amongst the applicants even though the applicants were far from united on the subject. Irish negotiators decided to raise its demands even higher by adopting the main strand of Oslo's negotiating strategy. As a result, the Commission now had to face demands from another applicant for equal treatment; offering it to one and denying it to another would prove difficult for Brussels to justify. In the months that followed, Dublin lobbied the Commission to grant the same terms to all the applicants. Manfred Caspari, a senior member of the Commission's negotiating team, believed that this was highly improbable. Norway, he argued, had "much bigger" problems than had Ireland, and he pointed out that the Community had already agreed to give special recognition to Norway's interests in the fisheries question. When Irish negotiators reiterated that the fisheries issue was a "big public opinion issue in Ireland" and that open access "would result in the complete spoliation of the fishing stocks in a very short time", Caspari repeated that Ireland would get a five-year period for the three-mile zone, and could "enforce conservation measures which would have to be non-discriminatory". ${ }^{27}$ The Commission hoped that suitable transition measures and a review of the conservation clauses in the CFP would be enough to end the discussions on the policy, at least with Britain, Denmark and Ireland. However, the Commission underestimated the growing level of opposition from the applicants to the policy.

Between May and June, Britain and Norway had each submitted very different proposals that would significantly restructure the original CFP; yet neither suited Dublin and on 7 June, Hillery presented counter proposals. ${ }^{28}$ London and Oslo approached the subject from the position that, if the CFP had to exist, then it had to be modified, yet Dublin sought to effectively scrap the policy in favour of the status quo. The London Fisheries Convention of 1964, which had been concluded after protracted discussions between the EEC six and three of the four applicants (except Norway), allowed the signatories to establish a 12-mile fishing limits from their coastlines. ${ }^{29}$ That Convention, Dublin suggested, should be maintained during the transitional

27. NAI, D/FA 2003/1/922, Minutes of meeting between Caspari and E.J. Brennan (Irish Embassy official, Brussels), 26.04.1970.

28. Agence Europe, 07.06.1971.

29. For more on the 1964 Convention, see J. FARNELL, op.cit., chapter 1; M. RASMUSSEN, op.cit., p.252. 
period and, before the end of this period, the entire situation would be reviewed by the enlarged Community. Effectively, the proposal aimed at maintaining the status quo in Europe's fishing industry. The plan alone carried little weight until the British delegation abandoned its own proposals and showed a real interest in the possibility of maintaining the status quo; this was not a solution favoured by Denmark who feared that a new post-enlargement fisheries policy would differ too drastically from the original plan. Added to this, the following day, the British delegation asked the Community to put forward its own proposals indicating how the fisheries problem could be resolved. London was anxious to find agreement on CFP related issues before the summer recess. Maurice Schumann, the French Foreign Minister, agreed and the Commission in cooperation with COREPER went to work with a mandate to find equitable solutions to the problems affecting the four applicants. The Commission had to ensure that the fine balance achieved on the CFP negotiations in the Council the previous October would be maintained. However, it also had to deal with the concerns of the applicants.

Although the Commission defended the main provisions of the policy in its compromise proposal that it sent to the Council, some flexibility was evident when these were revealed by mid-June. ${ }^{30} \mathrm{~A}$ transition period of ten years was proposed before the equal access provision would be introduced; this was an extension of five years under the original proposals. At the end of this transition period, the Commission would report to the Council on the social and economic situation in the Community's fishing regions and on the state of fish stocks. The transition period would be divided into two stages: the first five years would see the member states maintain an exclusive six-mile national fishing zone and during the second five-year period, the member states could continue to enforce the six-mile zone for local fishermen provided they depended essentially on inshore fishing. This six-mile zone was double the original proposal that had been bitterly rejected by the four applicants. The Commission also introduced a special exception regime for certain limited geographical zones that lacked alternative resources and employment. Britain, Norway and Denmark benefitted from this but the Commission did not include any regions of Ireland in this exception regime. In these special regions, a twelve-mile exclusive fishing limit would apply for five years. During the second five-year transition period, Council would decide if these exceptions would be extended. The Commission was unwilling to budge on the equal access provision apart from extending the transition period. It would have made very little difference to the overall compromise plan had Deniau and Mansholt included some regions of the Irish coastline to placate Dublin; it seemed like a clumsy omission. Unsurprisingly, Ireland rejected the compromise solutions and continued to promote its status quo plan. ${ }^{31}$

30. HAEC, BAC 134/1987, no.57/4, European Commission. Communication de la Commission au Conseil au sujet du problème de la pêche - document de travail, 17.06.1971.

31. HAEC, BAC 134/1987, no.57, Secretariat of the Council of Ministers, Négociation d'adhésion Rapport du Comité des Representants permanents au Conseil - problème de la pêche, 09.07.1971. 
The new proposals had in some ways strengthened the hand of the Irish negotiators. London's failure to achieve an increase in the six-mile limit pushed Britain closer to the Irish corner. Norwegian intransigence further helped Dublin and weakened the Commission's position, although Norway refused a British offer to hold bilateral meetings with the other applicants, and rejected the idea of attending a multilateral meeting in July between the Community delegation and the applicants. By the end of June, London had concluded that "we ought to move to adopt the status quo proposal put forward by the Irish". ${ }^{32}$ The Commission accepted that there were difficulties in reaching "une position commune" but made it clear that it was not prepared to either accept the objections of the applicants or rethink the CFP any further. The Commission continued to hold this line, and Mansholt defended it, in the Council in July before the enlargement conference adjourned for its summer recess. ${ }^{33}$

The period from October 1971 to January 1972 saw the most "intense, intricate and continuous" discussions taking place on the fisheries question. ${ }^{34}$ Dublin and Brussels tried to outmanoeuvre each other in their attempts to find an agreed solution to the CFP. By October, Dublin had built a strategy around convincing the Community to accept the status quo, and shelving the policy until after the four had joined the EEC. Unsurprisingly, the proposal did not find any supporters in the Commission.

In late October, Edmund Wellenstein, a senior Commission official, gave it a curt rejection during an intense meeting with Kennan. The status quo proposal was absolutely dead, "a non-starter", the Irish ambassador wrote to his colleagues in Dublin after Wellenstein repeated the Commission's objections. In a good example of Commission directness vis-à-vis the applicants, the Commission argued that there was no certainty that a new fisheries policy would be successfully negotiated after enlargement within any reasonable time; it had taken the Community over a decade to develop the original CFP. ${ }^{35}$

The Commission wanted the focus to remain firmly fixed on its compromise solutions rather than allow the applicants to set the agenda, although Wellenstein acknowledged that the Commission was preparing a new set of compromise solutions closely linked to their June proposals. Despite this, Dublin decided to maintain its opposition to the CFP and continued to push the status quo plan at the ministerial meeting in Brussels on 9 November "despite the pressure from the Commission". Dublin believed that there was still a chance that the status quo "will de facto turn out to be the eventual solution". Much of this hope rested on British support but if London accepted the Commission's compromise solutions

32. C. O'NEILL, Britain's Entry into the European Community: Report by Sir Con O'Neill on the Negotiations of 1970-1972, Frank Cass, London, 2000, p.267.

33. HAEC, BAC 259/80, no.168-174, PV 172, 2e partie, Minutes of European Commission meeting, 07.07.1971 and 14-15.07.1971.

34. C. O'NEILL, op.cit., p.270.

35. NAI, D/FA 2003/1/151, Kennan to Assistant Secretary D/FA, 26.10.1971. 
"it would of course weaken our position in favour of the status quo and would be very difficult for us to avoid getting into a negotiation on regions to get a quasi-permanent derogation up to 12 miles". 36

The strength of the Commission's and Ireland's policy positions rested largely on the support of others. The Commission relied heavily on the support of the six, and especially France, if its compromise solutions were to have any chance of success and the policy saved. The alternative presented by Dublin was a threat to the Commission only when this gained Britain's support and therefore became a serious option for consideration.

The British delegation had avoided any discussion on the CFP negotiations when the enlargement talks resumed after the summer recess. London wanted to keep the remaining CFP meetings off the agenda until after the House of Commons had voted on Community membership. However, without recalling the British position on the CFP, towards the end of the summer its stance on the Irish plan began to change. This was partly due to some gentle prodding from the Commission that indicated "the way out might be notional 6-mile limits for all, with extensions to 12 miles for special areas". This was more than the Commission had been willing to concede the previous June. Nevertheless, by early November the British cabinet recommended that the

"right course was to press ahead with our proposal for maintaining the status quo pending the negotiation of a new policy by the enlarged Community". 37

While London broadly supported the Irish plan, they continued, as did Ireland, to consider the Commission's revised proposals submitted through the Council. These were presented in early November. The morning session of the ministerial meeting on 9 November saw further gains for the British on the special exceptional regime of 12-mile limits but the Commission did not apply this to any part of the Irish coastline. British lobbying of the Commission had paid dividends when the two-stage transition period was scrapped and replaced instead with a single ten-year period, while a new review clause was also introduced. The more concessions that London received from the Community, the less inclined it was to support the Irish plan. Throughout November, and early December, Britain had won most of what it sought from the Community, and were ready to sign the Accession Treaty. The loss of British support was a major setback for Irish negotiators who were now forced to accept the CFP and negotiate exemptions for large sections of the Irish coastline. This was Dublin's "fallback position" when "the status quo proposal has no longer any chance of success". 38

The meeting on 9 November between Ireland and the Community proved acrimonious. Hillery, stressing that Ireland accepted the acquis, reminded the Community: "I think when the fisheries regulation came in, the day after or so, I did say that

36. NAI, D/FA 2003/1/151, Kennan to Seán Morrissey (Assistant Secretary D/FA), Suggested strategy, Ministerial negotiating meeting, 9 November 1971, 27.10.1971.

37. C. O’NEILL, op.cit., p. 270.

38. Kennan to Seán Morrissey, op.cit., 27.10.1971. 
this was not suitable to a Community of Ten". ${ }^{39}$ With no agreement in sight, Italy suggested that a special, unscheduled ministerial meeting would take place on 29 November, the aim of which was to bring an end to the fisheries saga. In the interim period, the Commission would liaise with the four applicants in order to iron out any remaining problems.

At the ministerial meeting on 29 November, the Community again presented new proposals that included designating only one part of the Irish coastline for the special twelve-mile regime. Dublin rejected this, and argued instead that other areas of the Irish coast had to be designated as qualifying for the special twelve-mile limit; Hillery argued that any criteria that could be used for the selection of the Northwest coast could apply "with equal justification to other areas of the Irish coast". ${ }^{40}$ Ideally, of course, Dublin wanted this limit extended around the entire coastline. A powerful display from Geoffrey Rippon before the Community negotiators on 29 November certainly put the CFP negotiations into perspective, perhaps for the first time since the enlargement talks had begun. Echoing comments made frequently by Hillery though never of the same ferocity or passion, Rippon argued that the fisheries policy could not be regarded as part of the real acquis because everyone was aware that it had been rushed to partial conclusion just before enlargement negotiations had begun. ${ }^{41}$ This intervention had the desired effect because the Commission was asked to prepare new proposals "en vue de favoriser une solution du problème". ${ }^{42}$

There was evident pressure on the Commission to take the debate out of the realms of legal intricacies into what the Community politicians oddly called the "political" and "economic" spheres. ${ }^{43}$ The original CFP had set no real provisions for conservation of fishing stocks, which was a major concern in Dublin (and Oslo). Ireland therefore submitted a provision designed to resolve this anomaly. Before 31 December 1982, Dublin wanted the Commission to present a report to the Council on the economic and social conditions of the coastal areas of the member states with particular reference to the development of the inshore fishing industry, and the state of fish stocks. This proposal was adopted by the Commission and presented to the Council on 11 December. The Commission had also cast aside its reservations about granting Ireland further concessions on the twelve-mile limits and the latter made additional gains. ${ }^{44}$ The Community also announced that from the sixth year after the entry into force of the Accession Treaty, the Commission would present the Council

39. NAI, D/FA 2003/1/472, Annex I, EEC Council secretariat conclusions of seventh ministerial meeting between Community and Ireland, 09.11.1971.

40. NAI, D/FA 2003/1/432, Notes of ministerial meeting between Community and Ireland, 29-30.11.1971.

41. M. WISE, op.cit., p.128.

42. HAEC, BAC 259/80, no.185-187, PV 187, 2e partie, Minutes of European Commission meetings, 29.11.1971, 01-02.12.1971.

43. M. WISE, op.cit., p.128.

44. See HAEC, BAC 134/1987, no.65/4, Secrétariat général du Conseil, Régime des droits de pêche (Déclaration faite par la délégation de la Communauté le 12 décembre 1971). The areas included the coast North and West of Lough Foyle as far as Cork in the Southeast, and the East coast from Carlingford Lough to Carnsore Point, for fishing of crustaceans and shellfish. 
with a review of the fishing conditions ensuring protection of the seabed, and preservation of biological resources of the sea. ${ }^{45}$ It was an important victory for Dublin. By the first week of January 1972, final agreement was reached on the fisheries question. ${ }^{46}$

\section{Conclusions}

The fisheries question was by far the most complex issue that dominated Dublin's relations with Brussels during the eighteen months of enlargement negotiations. The original CFP was one of the few Community policies that represented a tangible loss for Ireland's post-accession and one that would have political consequences for the governing Fianna Fáil Party. Many of the party's members, including the Taoiseach, Jack Lynch, all hailed from coastal constituencies. Hillery, for example, had been a member of parliament for Clare since 1951; water defines much of that county's boundaries. Ireland's chief negotiator would have been acutely aware of how the CFP's equal access provision would have impacted on fishing communities. Although no archival evidence has been found that shows pressure from the Irish fishing lobby, there was enough political awareness of the issue within government to force negotiators to adopt a hard bargaining position in Brussels. There was a political, as well as an economic, imperative to find a solution to the CFP. Complicating Dublin's efforts was the disunity among the four applicants, coupled with the Commission's determination not to disturb the delicate balance that it had achieved within the Council before the enlargement talks began. On its own, Ireland lacked the political support base to successfully challenge the acquis and the institutional actors that defended it.

Yet, the evidence does suggest that given the rather devious way that the CFP had been introduced, a united approach by the four might have resulted in the policy being shelved until after the negotiations had concluded. Dublin believed that once inside the Community, it would be able to wield enough influence (through membership of the Council, COREPER and with an "Irish" Commissioner) to revise the CFP. That policy position rested on securing the support of the other applicants, something it was unable to fully achieve. Norwegian negotiators believed it was better to strike a deal before rather than after accession and thereby securing an opt-out from much of the policy. Denmark, too, had little interest in siding with Dublin's status quo proposal. Copenhagen was broadly in favour of the original CFP so long as it was able to negotiate a solution for Greenland and the Faroe Islands. Although Britain had for a time during the talks supported Dublin, once London had received sufficient con-

45. NAI, D/FA 2003/17/256, Note from the secretariat of the Council of Ministers to applicants regarding arrangements for fishing rights, 12.12.1971.

46. See NAI, D/FA 2003/1/910, Official minutes of Fiftieth meeting of the Conference at Deputy Level, 05.01.1972. 
cessions from the Commission on extending fishing limits around the British coastline, its support ebbed away. Despite vague attempts to coordinate negotiating positions, there was no effort made between Copenhagen, Dublin and London; national interests differed too much to achieve cohesion.

The CFP negotiations highlighted the limited influence of an applicant state in influencing internal Community policy after agreement had been reached. Yet, the fisheries talks also exposed other issues such as the very real concerns for overfishing and conservation raised by Dublin, and the potential destruction of coastal communities that had heavily relied on fishing for centuries. These issues would resurface later in that decade with Spain's accession negotiations and when the EEC began to adopt a greater concern for protecting the Community's natural and declining resources. 